\title{
Re-formation of acute parietal epidural hematoma following rapid spontaneous resolution in a multitraumatic child: a case report
}

\author{
Çoklu yaralanma sonrası akut epidural hematom gelişen çocuk hastada \\ hematomun kendiliğinden hızlı rezolüsyonu ve tekrar oluşumu
}

\author{
Mehmet Bülent ÖNAL, ${ }^{1}$ Erdinç CIVELEK, ${ }^{2}$ Atilla KIRCELLİ, ${ }^{3}$ \\ Hakan YAKUPOĞLU, ${ }^{4}$ Tuna ALBAYRAK ${ }^{5}$
}

\begin{abstract}
Acute epidural hematomas resulting from traumatic brain injury remain among the most common causes of mortality and disability. In the literature, there are cases about the resolution and recurrence of spinal epidural hematomas. This case is characterized by the rapid disappearance and re-formation of an acute cranial epidural hematoma (EDH) associated with no overlying skull fracture. Various authors have reported resolution of EDHs managed conservatively, but rapid resolution and recurrence of cranial EDH was not reported before.
\end{abstract}

Key Words: Epidural; hematoma; trauma.
Travmaya bağlı beyin yaralanması sonrası gelişen akut epidural hematom ölüme ve ciddi sakatlığa sebep olabilen nedenlerden biridir. Literatürde, rezolüsyon sonrası spontan görülen spinal epidural hematom olguları bildirilmiştir. $\mathrm{Bu}$ olgu, kafatası kırığı olmaksızın spontan hızlı rezolüsyona uğrayıp sonrasında tekrar oluşan akut kraniyal epidural hematom (EDH) ile kendini göstermiştir. Çeşitli yazarlar spontan hızlı rezolüsyona uğrayıp konservatif takip edilen akut epidural hematom olguları bildirmişlerse de, aynı yerde tekrar oluşan EDH olgusu daha önce sunulmamıştır.

Anahtar Sözcükler: Epidural; hematom; travma.

\section{CASE REPORT}

A five-year-old boy was admitted to our emergency service after a fall from a height of 10 meters; his right parietal region hit the hard floor. The patient's mother reported loss of consciousness for a few minutes. His vital signs were stable at presentation. On neurological examination, the Glasgow Coma Scale (GCS) score was 15 , and direct and indirect papillary light reactions were intact. On his abdominal examination, minimal tenderness with palpation was present. In the first blood count, hemoglobin level was $12.3 \mathrm{~g} / \mathrm{dl}$ and white blood cell count was 20,000. All laboratory values were within the normal limits with no evidence of coagulopathy. On his plain X-ray, there were no fractures. He was consulted to the pediatric surgery and neurosurgery departments. Initial computed tomography (CT) approximately 30 minutes after the trauma demonstrated a right parietal epidural hemorrhage of $0.3 \mathrm{~cm}$ at its maximum thickness with no midline shift or calvarial fracture (Fig. 1a). However, neurologic and general status of the patient worsened in 1 hour (h). Because of his sweating, tachycardia of 160/min, hypotension, and no urine output, an urgently repeated blood count showed hemoglobin level of $4.5 \mathrm{~g} / \mathrm{dl}$. A second non-enhanced cranial tomography just $1 \mathrm{~h}$ after the initial tomography revealed total resolution of the epidural hemorrhage that had been seen on the previous CT scan (Fig. 1b). Abdominal CT showed abdominal free fluid, hepatic parenchymal heterogeneity and extravasation of contrast medium, which are
Departments of ${ }^{1}$ Neurosurgery, ${ }^{5}$ Anesthesiology and Reanimation, Siirt

State Hospital, Siirt; ${ }^{2}$ Department of Neurosurgery, Baskent University Istanbul Hospital, Istanbul; ${ }^{3}$ Department of Neurosurgery,

Goztepe Safak Hospital, Istanbul; ${ }^{4}$ Department of Neurosurgery, Medicana Ankara Hospital, Ankara, all in Turkey.

\footnotetext{
Siirt Devlet Hastanesi, ${ }^{1}$ Beyin ve Sinir Cerrahisi Kliniği, ${ }^{5}$ Anesteziyoloji ve

Reanimasyon Kliniği, Siirt; ${ }^{2}$ Başkent Üniversitesi İstanbul Hastanesi,

Beyin ve Sinir Cerrahisi Kliniği, İstanbul; ${ }^{3}$ Göztepe Şafak Hastanesi, Beyin ve Sinir Cerrahisi Kliniği, İstanbul;

${ }^{4}$ Medicana Ankara Hastanesi, Beyin ve Sinir Cerrahisi Kliniği, Ankara.
}

Correspondence (İletişim): Erdinç Civelek, M.D. Başkent Üniversitesi İstanbul Hastanesi Beyin ve Sinir Cerrahisi Anabilim Dalı, İstanbul, Turkey. Tel: +90 - 216 - 6519858 e-mail (e-posta): civsurgeon@yahoo.com 

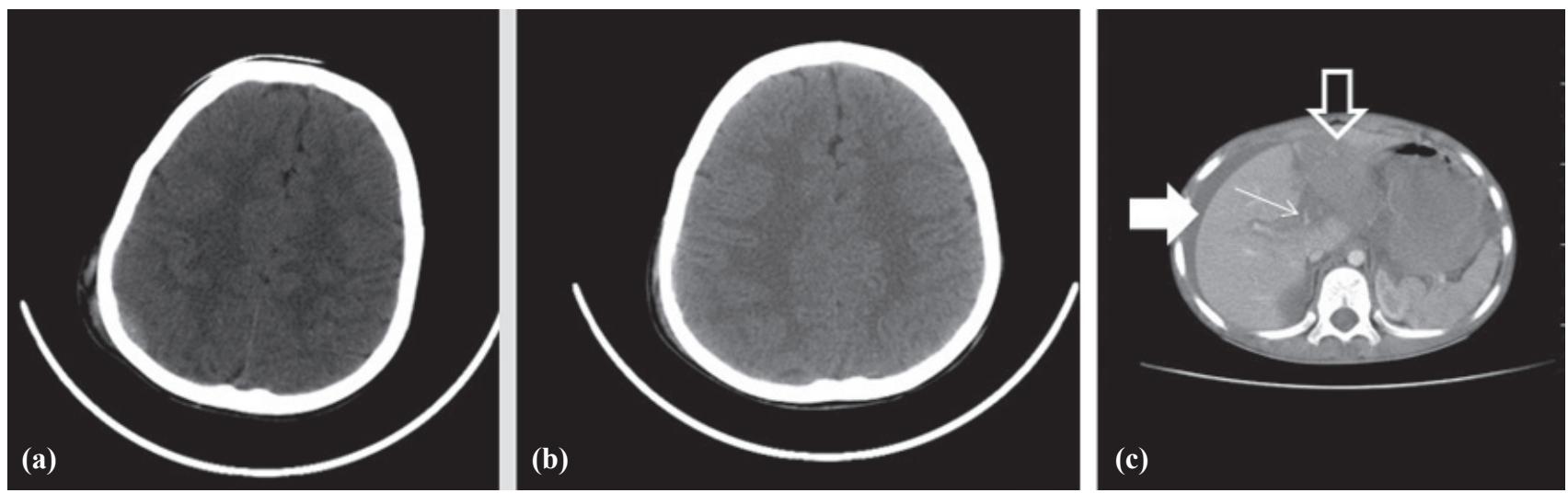

Fig. 1. (a) Initial non-contrast cranial CT revealed small right epidural hemorrhage. (b) Follow-up cranial CT showed disappearance of the previous hemorrhage. (c) Post-contrast abdominopelvic CT scan revealed hepatic artery injury (small arrow: extravasation of contrast medium, bold arrow: free abdominal fluid, open arrow: low attenuation of left lobe of the liver).

findings of hepatic artery injury (Fig. 1c). The patient was operated urgently. After the operation, the patient was admitted to the neurosurgical intensive care unit (ICU). The patient was under close clinical observation in the ICU. A 24-h granted access to emergency surgery in case of deterioration was provided during the entire hospital stay. His neurological and general condition was normal. Postoperative blood count after perioperative massive blood transfusion showed the hemoglobin level as $15 \mathrm{~g} / \mathrm{dl}$. In the morning, $6 \mathrm{~h}$ after the abdominal operation, he was confused, and an urgent control non-enhanced cranial $\mathrm{CT}$ revealed that dimensions of the right parietal epidural hemorrhage had noticeably increased $(1.7 \mathrm{~cm}$ at its maximum thickness) (Fig. 2a). The patient was anisocoric (rightsided mydriasis) at that time. He was taken to the emergency operation room for evacuation of the epidural hematoma $(E D H)$. In the postoperative period, repeat cranial $\mathrm{CT}$ showed complete resolution of the epidural hemorrhage (Fig. 2b). Postoperative abdominopelvic CT revealed necrosis of the left lobe of the liver and also minimal postoperative free fluid (Fig. $2 \mathrm{c}$ ). The patient was discharged from the surgical ward
10 days after injury with no neurological deficits.

\section{DISCUSSION}

Traumatic extradural hematoma is a neurosurgical emergency, and timely surgical intervention for significant EDH is the gold standard ${ }^{[1]}$ Incidence of acute $\mathrm{EDH}$ is estimated as $1.5 \%$ of patients treated for head injuries. ${ }^{[2]}$ Radiologically significant EDH is usually treated by urgent craniotomy and evacuation of the epidural blood clot. Smaller EDH can be treated conservatively with perfect clinical and radiological outcome. ${ }^{[3]}$ Balmer et al. ${ }^{[4]}$ reported good outcome after conservative management of children with a radiologically significant EDH who present with a normal neurological status; size alone is not an indication for surgical treatment of EDH. Various authors have reported resolution of EDHs managed conservatively, but rapid resolution of EDHs is rarely seen and reported by few. ${ }^{[5]}$ The first cases of spontaneous absorption of cranial EDH were reported by Weaver et al. in $1981 .{ }^{[6]}$ Servadei et al. ${ }^{[7]}$ reported that the majority of the cases having rapid spontaneous resolution of $\mathrm{EDH}$ are children. The spontaneous resolution process
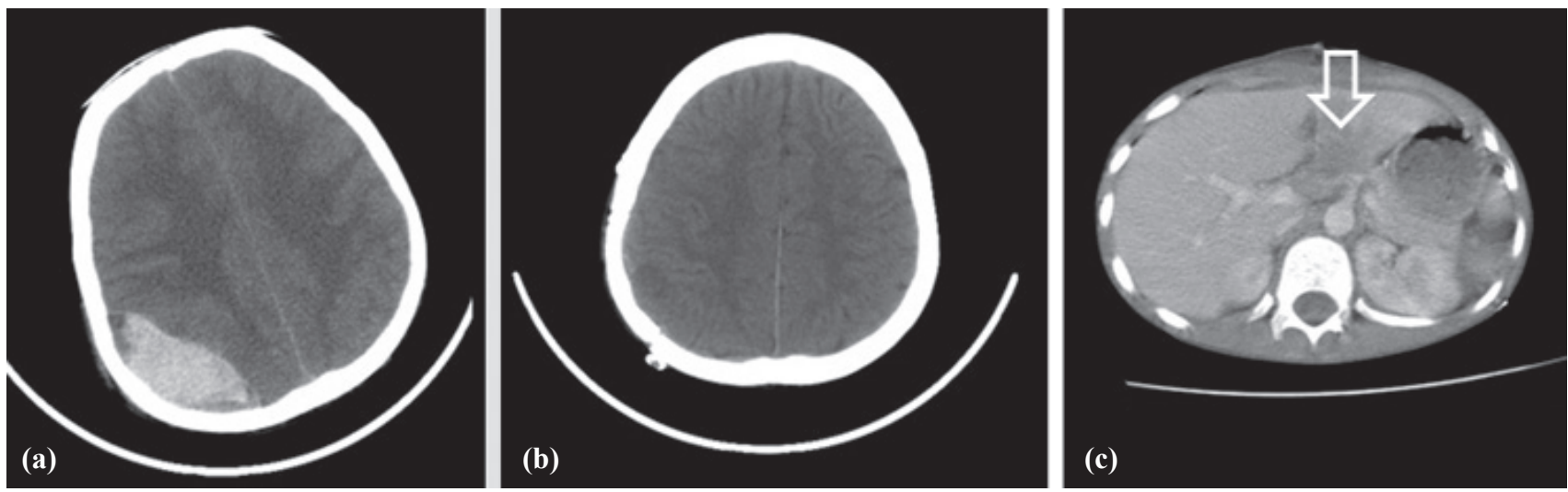

Fig. 2. (a) After abdominal operation, follow-up cranial CT was performed. Right epidural hemorrhage reappeared with increased dimension on follow-up CT. (b) Follow-up cranial CT after cranial operation: epidural hemorrhage showed complete resolution. (c) Follow-up abdominopelvic CT revealed necrosis of the left lobe of the liver (open arrow). 
during the natural course of acute EDH starts in the second week. ${ }^{[4]}$ Therefore, disappearance of an acute $\mathrm{EDH}$ within $24 \mathrm{~h}$ after trauma is extremely rare.

The cited mechanism of the resolution of an EDH differs; formation of a fibrovascular neomembrane and granulation tissue acting as an absorbing structure through sinusoid vessels and transfer of the clot into diploic bone or extracranial space through the fractures are two of the major hypotheses for spontaneous resolution. ${ }^{[5,7,8]}$ Because of time period needed for fibrovascular neomembrane formation, the first mechanism is thought to be in chronic EDH resolution. For the second mechanism, raised intracranial pressure by EDH helps the transfer of the hematoma to the subgaleal space through the skull fracture. In our case, there was no overlying skull fracture.

Tong et al. ${ }^{[9]}$ concluded that for patients with the first CT scan obtained as early as $2 \mathrm{~h}$ post-injury, a follow-up CT scan should be performed promptly. If the initial CT scan shows subarachnoid hemorrhage, brain contusion, or primary hematoma with brain swelling, an earlier and dynamic CT scan should be performed for detection of progressive hemorrhagic injury as early as possible, and the medical intervention would be enforced in time. Park et al. ${ }^{[10]}$ suggested that routine repeat CT within $24 \mathrm{~h}$ after blunt head trauma might minimize potential neurological deterioration in patients with either a GCS score lower than 12 or with an EDH or multiple lesions as indicated on initial CT.

This is the first case of spontaneous rapid resolution and re-formation of a traumatic epidural hemorrhage. There may be some specific pathophysiological mechanisms. First, systemic hypotension and cerebral hypoperfusion due to massive abdominal bleeding may cause cessation of epidural bleeding. Second, in children, the origin of an EDH is often venous, whereas in adults, it is mainly caused by an arterial bleeding. ${ }^{[4]}$ Venous lacerations may cause low tension bleeding. This may facilitate easy stoppage of the epidural bleeding. Third, blood transfusion for abdominal bleeding may cause coagulopathy. This may cause reformation of the EDH. In our case, a second non-enhanced cranial tomography just $1 \mathrm{~h}$ after the initial tomography revealed total resolution of the $\mathrm{EDH}$. This appearance may be due to the low hemoglobin level. In the CT, the blood with low hemoglobin level may appear as isodense.

In conclusion, we believe that the rapid disappearance of EDH during blood loss to the abdominal space and reformation of the acute EDH after blood transfusion (during abdominal operation) is due to the hemodynamic changes in the patient. In this type of patient, careful observation in an ICU as well as readiness to perform an immediate operation at any time and to secure adequate neurological observation are mandatory.

\section{REFERENCES}

1. Cheung PS, Lam JM, Yeung JH, Graham CA, Rainer TH. Outcome of traumatic extradural haematoma in Hong Kong. Injury 2007;38:76-80.

2. Taussky P, Widmer HR, Takala J, Fandino J. Outcome after acute traumatic subdural and epidural haematoma in Switzerland: a single-centre experience. Swiss Med Wkly 2008;138:281-5.

3. Chen TY, Wong CW, Chang CN, Lui TN, Cheng WC, Tsai $\mathrm{MD}$, et al. The expectant treatment of "asymptomatic" supratentorial epidural hematomas. Neurosurgery 1993;32:176-9.

4. Balmer B, Boltshauser E, Altermatt S, Gobet R. Conservative management of significant epidural haematomas in children. Childs Nerv Syst 2006;22:363-7.

5. Deniz FE, Türk CC, Ismailoğlu O, Bozkurt G, Ozcan OE. Rapid spontaneous resolution of epidural hematoma: a case report. Ulus Travma Acil Cerrahi Derg 2010;16:280-2.

6. Weaver D, Pobereskin L, Jane JA. Spontaneous resolution of epidural hematomas. Report of two cases. J Neurosurg 1981;54:248-51.

7. Servadei F, Staffa G, Pozzati E, Piazza G. Rapid spontaneous disappearance of an acute extradural hematoma: case report. J Trauma 1989;29:880-2.

8. Aoki N. Rapid resolution of acute epidural hematoma. Report of two cases. J Neurosurg 1988;68:149-51.

9. Tong WS, Zheng P, Xu JF, Guo YJ, Zeng JS, Yang WJ, et al. Early CT signs of progressive hemorrhagic injury following acute traumatic brain injury. Neuroradiology 2011;53:3059.

10. Park HK, Joo WI, Chough CK, Cho CB, Lee KJ, Rha HK. The clinical efficacy of repeat brain computed tomography in patients with traumatic intracranial haemorrhage within 24 hours after blunt head injury. Br J Neurosurg 2009;23:61721. 